\title{
FALLOT'S TETRALOGY WITH SOME FEATURES OF MARFAN'S SYNDROME AND SURVIVAL TO 58 YEARS
}

BY

\author{
A. S. ABRAHAM, M. ATKINSON, AND W. M. MITCHELL \\ From St. James's Hospital, Leeds
}

This report describes a woman with Fallot's tetralogy who led a moderately active life and survived to 58 years of age. It is of interest primarily on account of the long survival but also because of the association of stigmata of Marfan's syndrome.

\section{Case Report}

At the age of 19 years, being destitute, this patient was admitted to the workhouse where she was found to be mentally retarded and partially blind. A loud systolic bruit heard in the præcordium led to the diagnosis of congenital heart disease. Although remaining in institutions for the rest of her life, she worked as a ward maid and led a physically active existence for the next 25 years. At the age of 50 an attack of bronchitis was followed by persistent cyanosis and dyspnœa. Thereafter she suffered from recurrent chest infections, increasing cyanosis, and progressive impairment of exercise tolerance. Her final admission to hospital in December 1958 was on account of pleuritic pain in the left side of the chest, cough, and severe breathlessness of two weeks' duration.

Examination showed a deeply cyanosed, moderately dyspnœic, middle-aged woman who had gross finger clubbing, arachnodactyly, and a high arched palate. Vision was defective and the optic fundi could not be seen clearly, although each cornea appeared normal. Ankle and sacral œdema were present. The pulse was 112 a minute and of small volume and the blood pressure 140/90. The cardiac impulse was diffuse and a loud systolic murmur and thrill were present in the pulmonary area. A short diastolic murmur was audible in the left second and third interspaces. The chest was of emphysematous configuration: rhonchi were audible in all areas with numerous medium crepitations at the lung bases and a pleural friction rub in the left axilla.

The chest film (Fig. 1) showed cardiac enlargement with a shadow of the right-sided aortic arch projecting from the upper mediastinum on the right side. The lung fields were conspicuously clear. The electrocardiogram showed tall $\mathbf{P}$ waves and evidence of right ventricular hypertrophy.

Treatment with antibiotics failed to control the chest infection. Her condition steadily deteriorated and she died ten days after admission.

Post-mortem Examination. The significant findings were as follows.

Heart. Weight $450 \mathrm{~g}$. The right ventricular wall was hypertrophied and measured $1.0 \mathrm{~cm}$. in thickness; the left ventricle was normal in thickness $(1.2 \mathrm{~cm}$.). There was considerable dilatation of the right atrium but no atrial septal defect.

Pulmonary Artery and Valve. In place of the normal valve cusps, there was a thick conical diaphragm of firm white fibrous tissue, in the centre of which was a circular perforation, $0.5 \mathrm{~cm}$. in diameter. The narrow end of the conical diaphragm pointed away from the right ventricle. Several small nodules of calcification were found on the superior aspect of the conical valve. The main pulmonary trunk did not appear narrowed.

Although the aorta was not dilated, there was slight dextrorotation with over-riding of the right and left ventricles (Fig. 2). In association with this malformation, was a high ventricular septal defect, measuring approximately $1.0 \mathrm{~cm}$. in diameter. The aortic arch took its course over the hilum of the right lung, and is visible in Fig. 1. The main branches of the arch were also abnormal in position, both subclavian arteries arising from a common trunk on the right side, the left subclavian passing behind the osophagus. The common carotid arteries arose separately from the ascending aorta.

The cusps of the tricuspid, mitral, and aortic valves appeared normal. The coronary arteries were normal in position, and showed minimal atheroma.

The significant findings in the other organs were bronchopneumonia involving each lower lobe, a small focus of cerebral softening, $1.5 \mathrm{~cm}$. diameter, in the left frontal lobe, and generalized arteriosclerosis.

Histology. In view of the many reports of the occurrence in Marfan's syndrome of cystic medial necrosis in the aorta and the pulmonary artery (McKusick, 1955), these two structures were examined histologically. 


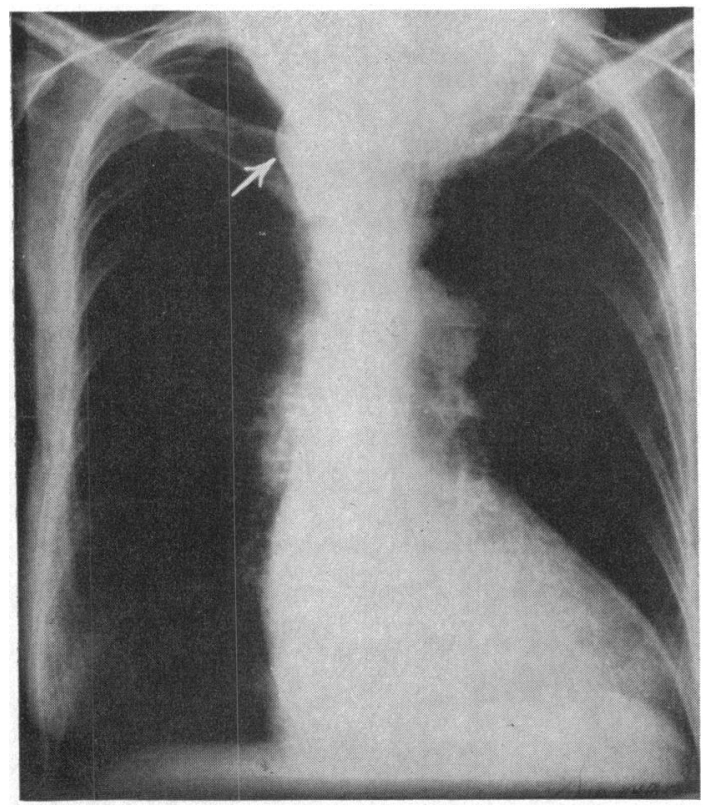

FIG. 1.-Chest film, showing an arrow pointing to the right-sided aotric arch on the right of mediastinal shadow.

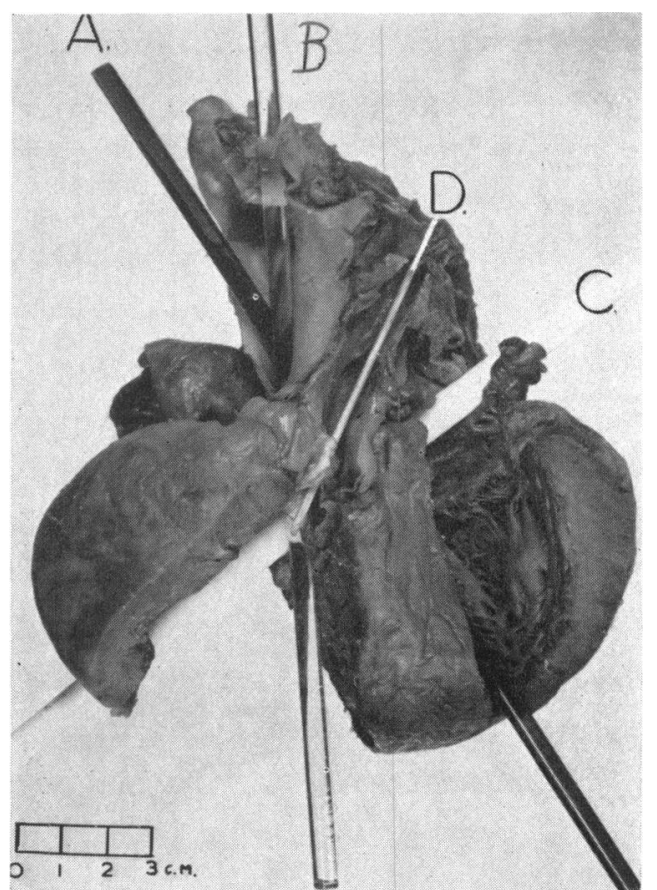

FIG. 2.-The heart opened to demonstrate features of Fallot's tetralogy. The black rod (A) runs from the left ventricle to the aorta. The transparent rod (B) runs from the right ventricle to the aorta. The white rod (C) passes through the ventricular septal defect from right ventricle to left ventricle. The narrow rod (D) runs through the conical and stenosed pulmonary valve.

In the pulmonary artery there was patchy fragmentation of the internal elastic lamina with overlying intimal hyperplasia: the elastic fibres of the media were also fragmented, but no areas of mucoid degeneration could be found. Apart from intimal hyperplasia, no abnormality could be seen in the wall of the aorta.

\section{Discussion}

The majority of patients with Fallot's tetralogy do not survive to adult life and Abbott (1936) estimated the average age at death to be 12 years. However, one of Fallot's patients lived to 36 and several patients who have reached the 4th and 5th decades have since been recorded (East and Barnard, 1938; Volini and Flaxman, 1938; Middleton and Ritchie, 1947; and Wood, 1956): the oldest patient in Wood's series was 42 years. Bedford (1956) reported the cases of two women, of whom one had died at the age of 52 and the other was still living at this age, Campbell (1958) described a woman still living at the age of 53, Strandell (1939) recorded one who lived to the age of 56, and Brumlik (1937) mentioned survival to 60 without giving any further information. The oldest patients with Fallot's tetralogy about whom clinical details are available were a noted American musician, who reached the age of 59 (White and Sprague, 1929), leading a reasonably active life until shortly before his death and making several tours abroad; a woman who lived to the age of 64 (Marquis, 1956); and a man who was active till 3 years before his death at 69 (Bain, 1954).

McKusick regards Marfan's syndrome as a defect of some element of connective tissue inherited as an autosomal dominant. It is characterized by abnormalities principally affecting the skeleton (a tall slender build, muscular hypotonia, arachnodactyly, high arched palate, and dental deformities), the eyes (notably dislocation of the lens) and the cardiovascular system (cystic medial necrosis of the aorta and pulmonary artery, septal defects, and valvular abnormalities). Incomplete forms of the syndrome may occur in various members of affected families (Whittaker and Sheehan, 1954).

So far, only three possible cases of Fallot's tetralogy associated with features of Marfan's syndrome have been reported. Van Buchem (1958) described a boy of 16 years with arachnodactyly, slight pulmonary stenosis, and a small ventricular septal defect. who was studied clinically and by cardiac catheterization. 
McKusick (1955) described two cases of Fallot's tetralogy associated with arachnodactyly and other skeletal abnormalities, but neither had ectopia lentis nor a family history of Marfan's syndrome. Our case appears to correspond with those of McKusick in that the presence of Fallot's tetralogy and skeletal abnormalities were not in doubt: although an ocular abnormality was present, unfortunately, its exact nature was not determined, nor was information about the family history available. Hence the diagnosis of Marfan's syndrome could not be fully substantiated.

We wish to thank Mr. J. Hainsworth for the photographs.

\section{References}

Abbott, M. E. (1936). Atlas of Congenital Heart Disease. New York.

Bain, A. C. (1954). Arch. Path. (Chicago), 58, 176.

Bedford, D. E. (1956). Proc. roy. Soc. Med., 49, 314.

Brumlik, J. (1937). Annuaire Soc. Tchecoslovaque Cardiol., 5, 109.

Van Buchem, F. S. P. (1958). Acta. med. Scand., 161, 197.

Campbell, M. (1958). Brit. med. J., 2, 1175.

Cockayne, E. A. (1935). Proc. roy. Soc. Med., 29, 120.

East, T., and Barnard, W. G. (1938). Lancet, 1, 834.

Fallot, A. (1888). Marseille méd., 25, 77.

McKusick, V. A. (1955). Circulation, 11, 321.

Marquis, R. M. (1956). Brit. med. J., 1, 819.

Middleton, W. S., and Ritchie, G. (1947). Amer. Heart J., 33, 250.

Strandell, B. (1939). Svenska Läkartidn, 36, 1513.

Volini, F., and Flaxman, N. (1938). J. Amer. med. Ass., 111, 2000.

White, P. D., and Sprague, H. B. (1929). J. Amer. med. Ass., 92, 787.

Whittaker, S. R. F., and Sheehan, J. D. (1954). Lancet, 2, 791.

Wood, P. (1956). Diseases of the Heart and Circulation. 2nd ed., London. 